\title{
Estudio de Antígeno Australia en 148 niños con Hepatitis Viral
}

\author{
IJES.: JOSE ZACARIAS S. *, LILLIAN MURILLO S. *. LUIS VALDIVIESO Z, *, PATRICIO BRINCK \\ M. " y MARTA VELASCO**.
}

La Hepatitis Viral en niños en nuestro medio adquiere características epidémicas en los meses fríos con intensificaciones cíclicas de los brotes cada 3-5 años (1).

Esta moda'idad epidémica de Hepatitis ha sido atribuida al Virus $\mathrm{A}$ aún no identificado. La hepatitis por virus B sólo se ve en forma esporádica en relación con transfusiones, inyecciones $y$ con menos frecucncia por contaminación oral (2). E1 virus $B$ se identifica con el Antigeno descrito por Blumberg (3) en un aborigen Australiano que actualmentc recibe diversas denominaciones: Antígeno Australia, Antígeno Asociado a Hepatitis ( $\mathrm{H} \mathrm{A} \mathrm{A),} \mathrm{Antigeno} \mathrm{de} \mathrm{Hepatitis} \mathrm{B} \mathrm{(} \mathrm{H} \mathrm{B} \mathrm{Ag.)} \mathrm{y}$ otros (4).

En la ctapa aguda precoz de la Hepatitis B el Antígeno Australia se encuentra presente casi en un $100 \%$ de los casos. disminuyendo Ia positividad en la evolución de la enfermedad (5).

El objetivo de este trabajo es investigar la frecuencia en que se encuentra Antígeno Australia en pacientes con Hepatitis Viral que han consultado en el Servicio de Hepatología del Hospital Luis Calvo Mackenna entre los años 1969-1972.

Material y MÉTodo. Se estudiaron 173 pacientes de los que consultaron por ictericia en el Servicio de Hepatología durante los años 1969. 1972. En 148 de estos niños se diagnosticó Hepatitis Viral en base a los hallazgos de la anamnesis, exámenes clínicos y de laboratorios. Las muestras de sangre fucron obtenidas el día de la primera consulta. En la figura $N$ To 1 se pucde observar la relación entre los días de cnfermedad y la toma de muestra de sangre. En algunos casos se tomaron 26 más muestras.

\footnotetext{
- Desartamento de Hepatologia, Hospital Luis Calvo Mackenna.
} * Departamento de Hepalologia, Hospital Salvador.

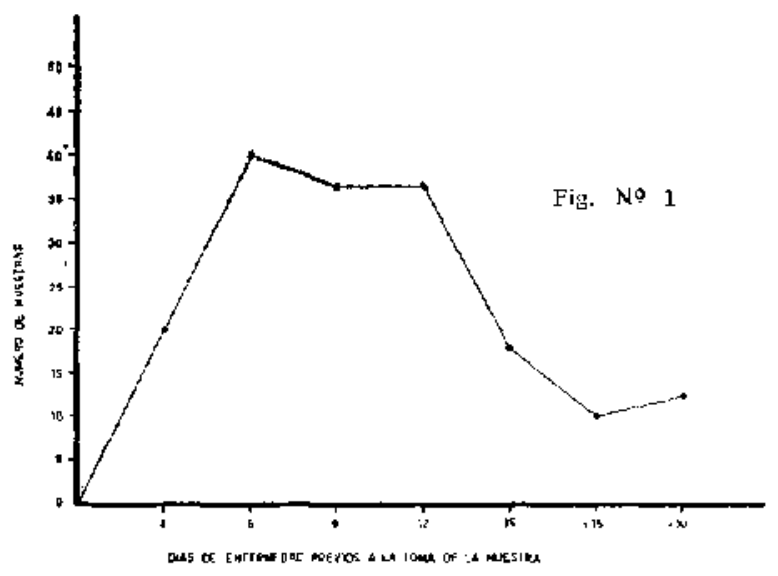

$\begin{array}{rlll}133 & \text { casos } & 1 & \text { muestra } \\ 18 & \text { casos } & 2 & \text { muestras } \\ 21 & \text { casos } & 3 & \text { muestras } \\ 1 & \text { caso } & 4 & \text { muestras. }\end{array}$

Las muestras de suero fueron guardadas a -20 grado Co hasta el año 1973. La determinación del Antígeno Australia se hizo con la técnica de Inmunoelectroforesis cruzada (6) en el Servicio de Hepatología del Hospital Salvador.

Resultados y comentarios. En la figura No 2 se obscrva la distribución por edad y sexo de los enfermos de Hepatitis Viral que fueron estudiados. Sc observó una mayor incidencia de $\mathrm{He}$ patitis entre los 2 y 7 años de edad, que es semejante a la encontrada en una investigación nuestra hace 8 años (1).

Las diferentes formas evolutivas de Hepatitis de los casos analizados aparecen en la figura Nọ 3. Catalogamos como prolongadas aquellos pacientes que evolucionan por un periodo mayor de 50 días con signos clínicos y/o de laboratorio en actividad mantenida o progresiva. 
ESTUDIO DE ANTIGENO AUSTRALIANO EN T48 CASOS DE HEPATTIS VIRAL. DISTFIBUTICN FOA EDAD Y SEXO.

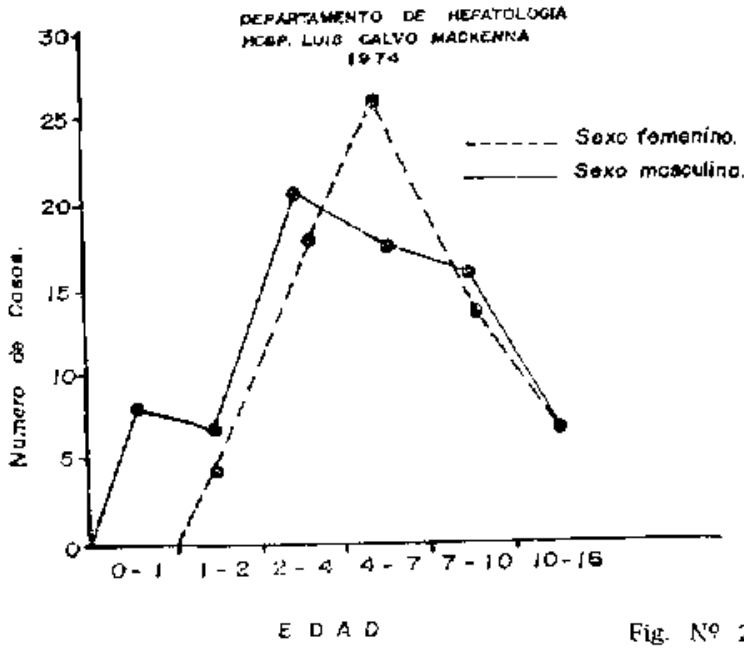

De los 148 casos de Hepatitis Viral se investigaron 211 muestras de suero, en ninguno se encontró Antígcno Australia. Sólo en uno se observó gran cantidad de Anticuerpo anti-antígeno Australia.

ESTUDIO DE ANTIGENO AUSTRALIANO EN 148 CASOS DE HEHATITIS VIRAL. FORMAS EVOLUTIVAS. DEPARTAMENTo de mepatologia hospital luis calyo mackenna
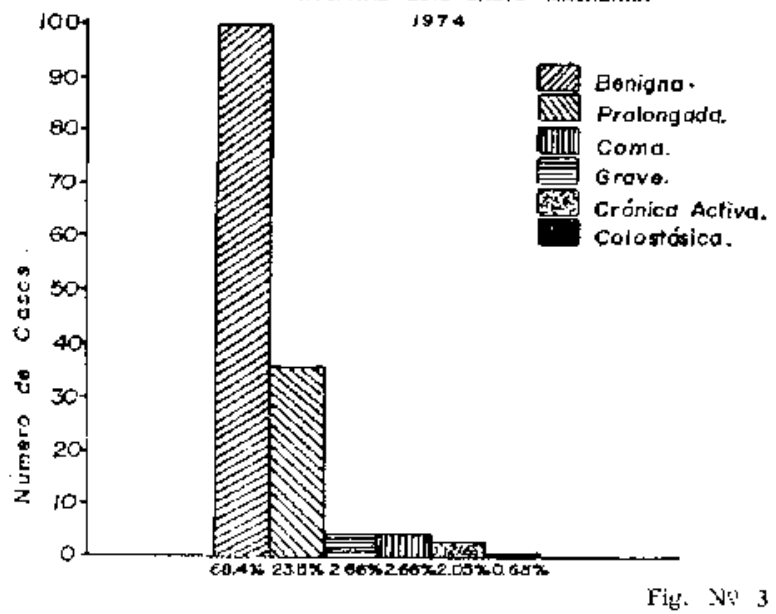

Esta muestra correspondía a una paciente que presentó una Hepatitis Viral que eyolucionó en 15 dias hacia una insuficiencia hepática aguda y coma Hepático. Recibió tratamiento conservador y una exanguíneo transfusión con lo cual se logró recuperar totalmente. Un mes y medio después del alta volvió a presentar ictericia, hepato. megalia y alteraciones de las pruebas funcionales hepáticas. En la muestra de sangre obtenida en el 1er. día de consulta de esta segunda hepatitis, se encontró anticuerpo anti antígeno Australia los cuales desaparecieron después de 15 días de evolución de su enfermedad. Este segundo episodio de Hepatitis se interpretó como producida por el
Virus B que probablemente lo recibió en la exanguínco transfusión. Se pesquisaron los dadores del pool de sangre utilizada, pero todas las muestras resultason negativas para Antígeno Australia.

Finalmente podemos concluir que las Hepatitis virales en niños en nuestro medio son en su mayoría Antígeno Australia negativo y en un alto porcentaje causados por el Virus A. Las Hepatitis B asociadas al Antígeno Australia es poco frecuente en niños y se observa en forma esporádica en aquellos pacientes que han recibido el virus por vía parenteral (inyecciones, instrumentaciones o transfusiones) o lo que sucede con menos frecucncia por vía oral.

\section{RESUMEN}

En 148 niños con Hepatitis Viral se obtuvieron 211 muestras de suero para investigar la presencia de Antigeno Australia.

En ningún caso se cncontró Antigeno Australia, sólo en un paciente se pesquisó anti cuerpo anti Antígeno Austratia: correspondió a una muestra de suero obtenida en una $2^{a}$ hepatitis dos meses después de haber sido tratada con exanguineo-transfusión y corticoides por una hepatitis fulminante y coma hepático.

\section{SUMMARY}

Australia Antigen was investigated in 211 serum samples obtained from 148 children with acute viral hepatitis.

All the samples studid were negative for Australia Antigen. Anti Australiz Antigen antibody was found in one patient, who came down with a second viral hepatitis two months after she was treated with exchange transfusion for a viral hepatitis complicated with hepatic coma.

This finding confirms that acute virat hepatitis among our chikdren is mainly produced by Virus $A$.

\section{REFERENCIAS}

1.-Zacarias, J., Soria, M. y Negron, A. Aspectos epidemiológicos, clínicos y de laboratorio de la Hepititis Viral en niños. Rev. Chilena de Pediatría, 39: 609,1968 .

2.-Krugman, S. Giles, J. P. and Hammond, J. Viral Hepatitis Type B (MS-2 Strain) Studies On Active Immunization. JAMA. 217: 41, 1971.

3.-Blumberg, B. S. Alier, H. J. and Visnich, S. A "New" Antigen in Leucemia Sera. JAMA. 191: $541,1965$.

4.--Carver, D. H. and Seto, D. Hepatitis A and B. Pediatric Clinic of. N. A. 21: 669, 1974.

5.- Krusman, S. Viral Hepatitis and Australian Antigen. J. of Pediatrics. 78: 887, 1974.

6.-Gorks D. J. and Howe, C. Rapid detection of Australia Antigen by counter immunoelectrophoresis. J. Inmunology 104: 1031, 1970. 